\title{
Which age group spends the most in a national park?
}

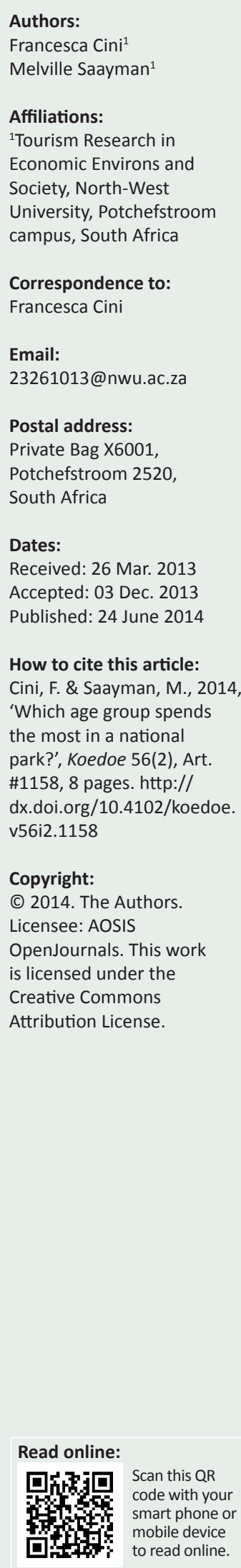

Age (and its changing structure amongst the wider population) is one of the most relevant aspects required to better understand and forecast the needs, interests and associated consumption behaviours of tourists. This research used age to investigate the expenditure patterns amongst a sample of visitors to the Table Mountain National Park (TMNP), South Africa. In March 2010, visitors to the TMNP were found to differ significantly from those at other parks, as they were younger and most of them were foreigners. This study found that younger visitors (18-29 years) were higher spenders when compared to those aged 30-49 years. As parks are generally visited by older people, this study showed the economic importance of the younger market. The research also made clear implications and recommendations for park management as to how to address these findings.

Conservation implications: Conservation is dependent on funding. One of the main sources of income is tourism and tourism related activities. This research can assist marketers and managers to target the right markets in order to be more sustainable. This research also shows the importance of environmental education at an early age in order to grow awareness and to target the right markets.

\section{Introduction}

The economic importance of natural protected areas is recognised at both national and international levels. Since the 2003 World Parks Congress in Durban, South Africa, the view of economic development and nature conservation as opposite realities is changing. In this way, a new paradigm for protected areas was fostered: the synergy between conservation and sustainable development was forged. Protected areas were seen as providers of benefits beyond boundaries - beyond their boundaries of nation-states (International Union for Conservation of Nature [IUCN] 2004b). The relationship between economic development and nature conservation became increasingly important, especially in developing countries, because conservation areas can be used as a tool for poverty alleviation (Buckley 1994, 2002a; Bushell \& McCool 2007; Bushell, Staiff \& Eagles 2007; Butler \& Boyd 2000; Geldenhuys \& Saayman 2009; Myburgh \& Saayman 1999; World Commission on Protected Areas 1998; World Tourism Organization 2002; World Wildlife Fund 2001). Practical, protected areas can provide a number of benefits to the poor. For instance, they can provide some ecosystem services including coastal protection, water purification and carbon sequestration. They also can provide some options for income by providing jobs in the tourism industry. For instance, in countries such as South Africa, Zimbabwe and Zambia, local communities obtain income from sport hunting (Child \& Dalal-Clayton 2004; IUCN 2004a).

In many countries, government funding for parks is reducing in real terms (Buckley 2002b; Eagles, McCool \& Haynes 2002; Mabunda \& Wilson 2009; Saayman 2009); therefore, it is becoming increasingly important to attract markets that can generate capital that can be used for sustainable development. Then, particularly for Third-world countries, finance generated and secured from tourism can represent the basis for nature conservation and preservation, as well as for the eradication of economic and social inequalities. In addition, it can provide benefits such as an increase in local jobs, higher local income, higher education level of local people and equal access to quality and affordable basic services (Eagles et al. 2002). As promoting the mere increase in the number of visitors to capture economic benefits might be somewhat risky in terms of the negative impacts on the natural environment (see Eagles et al. 2002), a possible de-marketing strategy might be developed for targeting only those segments with the stronger propensity to spend.

\section{Literature review}

The characteristics of consumers as demographic, behavioural (including the expenditure patterns) and psychographic are widely considered the key elements of a marketing strategy. 
Identifying the factors linked to tourists' motivations, preferences and behaviours is crucial to foreseeing their potential travel choices (Cha, McCleary \& Uysal 1995; Frochot \& Morrison 2000; Kotler 1992). Specifically, age (and its changing structure amongst the wider population) is one of the most relevant aspects that is considered to better understand and forecast the needs, interests and associated consumption behaviours of tourists (Gibson, Attle \& Yiannakis 1998; Johns \& Gyimóthy 2002; Jönsson \& Devonish 2008; Moutinho 1987; Oh et. al. 2004; Patterson \& Pegg 2009; Seaton 1996). In Western countries, the size of the older population (55 years and older) is growing at a faster rate than the younger one and represents new target tourist markets that are healthier, affluent and have a greater desire for novelty and escape than do those of previous generations (Patterson \& Pegg 2009; Sherman \& Schiffman 1991). The use of age as a segmentation variable is supported by several research articles that found age to be one of the primary variables, which explained the differences in people's travel interests preferences and behaviours.

To date, several studies found age as one of the main variables in affecting even travel expenditure patterns as a type of travel behaviours (Thrane \& Farstad 2011). For example, in a study conducted by Mok and Iverson (2000), age significantly characterised the different spending segments. Specifically, heavy spenders were younger than 50 years old. Again, Jang, Ismail and Ham (2002) found that association amongst a sample of Japanese outbound travellers. Specifically, this study revealed that heavy spenders were older, had a larger party size and a longer length of stay. In addition, Saayman, Saayman and Du Plessis (2005) found differences between heavy and light spenders according to their age amongst visitors to the World Cup Cricket matches in South Africa. Specifically, heavy spenders were older than 35 years old and spent more on accommodation, restaurants and souvenirs, compared to the younger ones. In most studies, profiling the spending segments was conducted using sociodemographics such as age, level of education, annual income, place of residence and trip characteristics such as travel party size, length of stay and type of accommodation.

With specific regard to the relationship between travellers' age and their use of natural areas, for instance, a study conducted by Kim, Lee and Klenosky (2003) amongst visitors to a national park found out that the younger group (less than 50 years) was motivated mainly by the possibility of experiencing adventure and sharing their friendship, whilst the older visitors ( 50 years and older) by the possibility of appreciating the natural resources and enhancing their state of health. Also Moscardo and Green (1999) found an overall decline in activity participation associated with age, particularly for activities associated with nightlife and entertainment and outdoor, physical, nature-based activities. Analysing travellers by age can also have important implications for the management of a tourist destination. Types of facilities and access to infrastructures, for example, might be planned on the basis of visitors' age. Strongly associated with people's income and expenditure patterns
(Down 2000), age was found as one of the main variables affecting even travel expenditure patterns (Jang et al. 2004; Saayman et al. 2005).

However, a review of the literature revealed a dearth of studies aimed at investigating the expenditure patterns (behavioural characteristics) amongst nature-based tourists, or even of expenditure behaviours by their age. Amongst the few, a study conducted by Mehmetoglu (2007) investigated the relationship between the daily expenditures and the trip activities of a sample of visitors at two nature-based attractions in northern Norway. Heavy spenders were more likely to consider nature-based activities when compared to the light spenders who, instead, attached more importance to visiting museums and attractions. Whilst motivational differences amongst the spending groups were partially supported by the study, income and age were found to significantly influence their expenditure patterns. Specifically, older nature-based tourists ( 50 years and older) were more likely to be lighter spenders than were younger ones. Another study looked at the variables that influence spending patterns and made recommendations to attract high-spending markets to the Tsitsikamma National Park in South Africa (Kruger, Saayman \& Saayman 2010). Respondents segmented by their real expenditure per person per day showed differences based on their age. Two different markets were identified, (1) 'highspenders', aged 35-49 years and older than 50 years, more likely to stay in chalet accommodations and to have a longer stay at the park and (2) 'low-spenders', aged 35-49 years old, more likely to stay in camping accommodations and have a shorter stay at the park. However, some other studies of the field did not include age as a segmentation variable (Downward \& Lumsdon 2004) or did not detect any significant relationship between expenditure patterns concerning age (Chhabra 2007; Spotts \& Mahoney 1991).

Since age has been found as one of the most relevant aspects that is considered to better understand and forecast the needs, interests and associated consumption behaviours of tourists, as mentioned above, further research is required on this aspect to provide more precise information for marketers. Comparing groups of visitors by age with regard to their expenditure patterns will possibly allow both known and new age lucrative markets to national parks to be explored. This will be useful when proposing strategic plans to grow visitation figures amongst those nature-based segments with the highest propensity to spend. This is particularly important for less developed countries, where a large portion of the world's biodiversity is concentrated and where the finance generated and secured from nature-based tourism can foster and support the sustainable development of an area.

Based on this, the purpose of this article is to use age to investigate the expenditure patterns amongst a sample of visitors to the Table Mountain National Park (TMNP), along with other socio-demographics and their reasons for the visit. The latter data are to assist with profiling the age groups and to match the 'product's' specificities with the public's specific demands. 


\section{Research method and design Setting}

The TMNP is one of 22 national parks in South Africa and was officially established in 1988. It stretches from Signal Hill in Cape Town to Cape Point at the southern end of the Cape Peninsula and covers 25000 ha. This urban park is famous because of Table Mountain itself, its historical and cultural heritage and its World Heritage status. South African National Parks (SANParks), which is the custodian of national parks in South Africa, indicated the promotion of the country's nature-based tourism as one of its core pillars. Without compromising sustainability, self-generated revenues from commercial operations are considered necessary to supplement government funding of conservation management. The TMNP is amongst the five top South African parks with the highest number of guests. Statistics for 2011 reported 2344340 guests for the TMNP, followed by the Kruger National Park with 1411796 guests, the West Coast National Park with 201137 guests, the Tsitsikamma National Park with 180107 and the Addo National Park with 138079 guests. Compared to the previous year (2010), total guests-to-parks numbers increased by 3.6\%. Specifically, the TMNP increased by 5.6\%, whilst the Kruger National Park increased by 1.8\% (SANParks 2012).

The main reason for selecting the TMNP was that this Park attracts a large number of visitors and shows the highest representation of international tourists, as well as a more equal spread of respondents over different age groups, compared to other South African national parks (Saayman, Kruger \& Fouche 2009). This can be explained by the facts that TMNP is a scenic Park, offering the 'Majestic Mountain' as one of the new seven wonders, together with ocean views, mountains, beaches, forests and a variety of popular recreational activities.

\section{Design}

The study sample included day visitors to the park from 27 March to 01 April 2010. Six fieldworkers (three groups of two) approached visitors whilst they were queuing at the three popular entry points to the Park: the cable car to Table Mountain, Boulders and Cape Point. It is difficult to have fieldworkers at all entry points as there are also open access areas; therefore, it was decided to focus on these three, as they could be considered the most important access points and tourists generally visit all these areas.

Those visitors who expressed willingness to take part in the research were first asked a number of screening questions to detect the expenditure patterns from only one member per family or travel group. This information avoided repeat data and biases in the actual expenditure patterns amongst the respondents. In total, 441 questionnaires were collected during the study period, of which 404 were usable after a preliminary screening. According to Israel (2009), in a population of $>100000(N), 398$ respondents $(n)$ are seen as representative and result in a $95 \%$ level of confidence with a $\pm 5 \%$ sampling error. Thus, 404 usable questionnaires were deemed sufficient for the purposes of this study.

\section{Procedure}

The research used a structured self-administered questionnaire, developed on the basis of the questionnaires used by past researchers (Oberholzer et al. 2009; Saayman, Saayman \& Ferreira 2009). The questionnaire consisted of three main sections, (1) socio-demographic details, (2) expenditure patterns and (3) reasons for the visit.

\section{Socio-demographics}

Taking into consideration the goal of this study, age was considered pre-eminent compared to the other sociodemographic characteristics gathered here and this factor was detected by an open-ended question: 'year of birth'. The respondents' ages were calculated and post-coded in groups on the basis of the strong association found between age and household finance (income and expenditure) (Down 2000; Mok \& Iverson 2000). Only respondents over 18 years of age were surveyed, as they are more likely to travel by themselves and have money to spend. Respondents were categorised into one of the following four age groups: 18-29 years, 30-49 years, 50-64 years and 65-74 years (see Table 1 ).

The age groups were characterised based on the expenditure patterns per day per person, together with a trip-related characteristic, reasons for the visit and other sociodemographics. Two other socio-demographic details were also included in the questionnaire to assist with profiling the age groups: 'region of residence' and 'education' ('no school', 'Matric', 'degree', 'postgraduate', 'professional' and 'other'). The region of residence was post-coded as follows: 'North America', 'Australasia', 'Europe', 'South Africa' and 'Other countries'. Finally, a question about the awareness of being in a national park was included. A dichotomous response format ('yes' or 'no') was used.

\section{Expenditure patterns}

The expenditure patterns section was developed based on past research (Kruger et al. 2010; Saayman, Van der Merwe \& Pienaar 2009). Spending behaviours were captured as follows: 'money spent for categories or services per person' ('entrance and conservation fee', 'restaurants', 'food', 'beverages', 'transport to the park', 'activities', 'souvenirs and jewellery') and 'number of people paid for' (including the respondent). On the basis of responses to 'money spent for categories or services', the total expenditure was calculated. To compute the total expenditure per person, the total expenditure was divided by the number of people paid for.

TABLE 1: Location of respondents by age group in Table Mountain National Park.

\begin{tabular}{lcccc}
\hline \multirow{2}{*}{$\begin{array}{l}\text { Age groups } \\
\text { years) }\end{array}$} & \multicolumn{3}{c}{ Location (Frequency) } & Total \\
\cline { 2 - 4 } & Boulders & Cape Point & Table Mountain & \\
\hline $18-29$ & 36 & 38 & 56 & 130 \\
$30-49$ & 62 & 33 & 101 & 196 \\
$50-64$ & 7 & 7 & 15 & 29 \\
$65-74$ & 21 & 15 & 13 & 49 \\
\hline
\end{tabular}




\section{Reasons for visiting the Park}

One measure that was developed ad hoc for this study concerned the reasons for visiting the Park and the age groups were also characterised according to this. These reasons were found to be connected to age and can be considered amongst the most important personal variables for a better understanding of the consumers' profile (see Crompton 1979; Crompton \& Mckay 1997; Iso-Ahola 1999). The scale for this question was developed based on common motivations identified from the tourism literature (Crompton 1979; Kim, Jogaratnam \& Noh 2006; Kruger \& Saayman in review; Richards \& Wilson 2003), which include, (1) relaxation and getaway, (2) knowledge, (3) family togetherness, (4) natural beauty admiration and (5) activities participation. The scale included 26 items (four to five for each motivation) and participants were asked to indicate the importance of each item using a 5-point Likert scale ( $1=$ 'not at all important', 2 = 'less important', 3 = 'important', 4 = 'very important', 5 = 'extremely important'). The relaxation and getaway motivation included items such as, 'to get away from routine' and 'to relax'. The knowledge motivation items included, 'learn about plants and animals' and 'learn more about specific marine life'. The family togetherness motivation included statements such as, 'family recreation' and 'benefit of children'. The natural beauty admiration motivation included items such as, 'TMNP is world renowned' and 'for the scenic beauty and view'. Finally, the activities participation included statements such as, 'mountain biking' and 'surfing'.

\section{Analysis}

Statistical data analysis was performed using SPSS version 18 (2009). The four age groups were characterised using Chi-square, Kruskal-Wallis and analysis of variance (ANOVA) tests based on expenditure patterns, along with psychographics (reasons for visiting the park) and sociodemographics.

\section{Results}

\section{Respondents' profile}

In the TMNP, the largest group of respondents (196, 48.5\%) were 30-49 years old. This was followed by those aged $18-29$ years $(130,32.2 \%)$. Fewer in number were respondents aged $65-74$ years $(49,12.1 \%)$ and those aged $50-64$ years $(29,7.2 \%)$. During the 5-day study period, the average age of respondents was 41.3 years (s.d. $=15.69$ ).
The median of the total expenditure per respondent per day person was R125 and the majority of respondents (71.2\%) said that they had paid for one or two people, including themselves. This group was followed by those respondents who paid for three or four people (22.7\%).

The majority of respondents were well-educated, with $37.6 \%$ holding a degree, $22.6 \%$ in professional occupations and $18.3 \%$ holding a postgraduate qualification. This result, too, is consistent with previous research (e.g. Marques, Reis \& Menezes 2010; Saayman \& Slabbert 2004; Saayman, Kruger \& Fouche 2009; The International Ecotourism Society 2006).

From this study, it was found that the TMNP is attracting a higher percentage of international tourists compared to local tourists. Almost half $(46.1 \%)$ of the visitors to the TMNP were foreigners from Europe. South African tourists made up almost one-third of all respondents (28.9\%), whilst North Americans represented one-tenth (10.7\%). In contrast, previous research at other South African national parks (Saayman, Kruger \& Fouche 2009) highlighted a higher percentage of local visitors compared to international ones.

\section{Reasons for Park visit}

A principal component analysis with oblimin rotation supported a five-factor structure, explaining $71 \%$ of the total variance:

- 'activities and adventure sports performance'

- 'Park's attributes admiration'

- 'knowledge and inner experience'

- 'escape'

- 'social interactions'.

The scree plot of eigenvalues suggested that no further factors contained reliable systematic variance. Satisfactory reliabilities were observed for the scale scores $(0.95,0.68,0.84$ and 0.79 ) with the exception of social interactions (0.51). The results are shown in Table 2.

Factor scores, calculated as the average of all items contributing to a specific factor, indicated the most important reasons for visiting the park were, 'escape' (3.49), followed by 'Park's attributes admiration' (3.46). Less important reasons were 'social interactions' (3.28), 'knowledge and

TABLE 2: Principal component analysis on respondents' motives for visiting Table Mountain National Park.

\begin{tabular}{|c|c|c|c|c|c|}
\hline \multirow{2}{*}{$\begin{array}{l}\text { Motives for visiting } \\
\text { the park }\end{array}$} & \multicolumn{5}{|c|}{ Factors } \\
\hline & $\begin{array}{l}\text { Activities and adventure } \\
\text { sports }\end{array}$ & $\begin{array}{l}\text { Park's attributes } \\
\text { admiration }\end{array}$ & $\begin{array}{l}\text { Knowledge and inner } \\
\text { experience }\end{array}$ & Escape & Social interactions \\
\hline Loadings range & $0.70-0.91$ & $0.56-0.91$ & $0.40-0.85$ & $0.53-0.89$ & $0.66-0.60$ \\
\hline Number of items & 9 & 4 & 5 & 3 & 2 \\
\hline Items & $\begin{array}{l}\text { - 'mountain biking' } \\
\text { - 'dog walking' } \\
\text { - 'surfing' } \\
\text { - 'rock climbing' } \\
\text { - 'fishing' } \\
\text { - 'overnight trails' } \\
\text { - 'picnic and braai' } \\
\text { - 'day hiking routes' } \\
\text { - 'birding' }\end{array}$ & $\begin{array}{l}\text { - 'TMNP is world renowned' } \\
\text { - 'mainly visit TMNP' } \\
\text { - 'photographic purposes' } \\
\text { - historical attractions' }\end{array}$ & $\begin{array}{l}\text { - 'develop an appreciation } \\
\text { for endangered species and } \\
\text { marine life' } \\
\text { - 'learn more about specific } \\
\text { marine life' } \\
\text { - 'learn about plants and } \\
\text { animals' } \\
\text { - 'learn more about nature' } \\
\text { - 'spiritual experience' }\end{array}$ & $\begin{array}{l}\text { - 'to get away from routine' } \\
\text { - 'to relax' } \\
\text { 'to explore' }\end{array}$ & $\begin{array}{l}\text { - 'family recreation' } \\
\text { - 'benefit of children' }\end{array}$ \\
\hline
\end{tabular}

TMNP, Table Mountain National Park. 
inner experience' (3.12) and 'activities and adventure sports performance' (2.26). These results are similar to those of studies at other South African national parks (Saayman, Kruger \& Fouche 2009), which, in most cases, found the main reason for visiting national parks was the need to escape and relax.

\section{Expenditure patterns by age}

The Kruskal-Wallis test was used for continuous variables that displayed a non-normal distribution. The respondents aged 18-29 years reported the highest expenditure per person and a higher expenditure per person per day when compared to the older group aged 30-49 years. Specifically, the median expenditure for the group aged 18-29 years is R160 and the median for the group aged 30-49 years is R120. The former group was above, whilst the latter was slightly below the overall median, which was R125. No significant statistical differences could be established between the groups aged 18-29 years and 30-49 years and the groups aged 50-64 years and 65-74 years, although the median of the expenditures per person was noticeably less than for the groups younger than 50 years. This is because, on the one hand, the older groups (50-64 years and 65-74 years) were fewer in numbers (29 and 49 respondents, respectively) whilst, on the other hand, few of them provided information about their expenditure patterns (10 and 15 respondents, respectively) (see Table 3).

Most of the travel expenditures were allocated to entrance and conservation fees $(48 \%)$, whilst smaller percentages characterised restaurants $(16 \%)$, transport $(9 \%)$, food $(8 \%)$ and activities (8\%). However, no significant differences were found amongst the age groups in expenditures per person for each of these categories.

\section{Segment characterisation}

An ANOVA analysis on the five psychographic characteristics found significant differences for the motivational dimension 'social interactions' by age groups $(F=3.18, d f=3 / 356$, $p<0.05)$. Respondents aged 18-29 years or 30-49 years were more likely to be motivated for the visit by the possibility of being with family (or someone special) or with friends, when compared to the group aged 65-74 years. However, these results should be interpreted with scepticism because of the low reliability of the scale (see Table 4).

Statistically significant differences were also found for the awareness of being in a national park $\left[\chi^{2}(3=397)=8.12\right.$, $p<0.05]$. Interestingly, although the majority of visitors amongst all age groups were aware, a higher number of younger respondents aged 18-29 years (21 out of 44) and those aged $30-49$ years (20 out of 44 ) stated they were unaware that they were in a national park, compared to the older groups.

Statistically significant differences were also found in the region of residence $\left[\chi^{2}(9=353)=30.1, p<0.01\right]$. In particular, more respondents aged 30-49 years $(45.3 \%$ and $31.8 \%$, respectively) and $18-29$ years (31.8\% and $32.5 \%$, respectively) came from Europe and South Africa, compared to the older groups. Older respondents aged 50-64 years (46.2\% and $26.9 \%$, respectively) and $65-74$ years $(44.2 \%$ and $30.2 \%$, respectively) came from Europe and North America (see Table 5).

The education level of three groups also differed $\left[\chi^{2}(12=385)=47.12, p<0.01\right]$. Whilst most of the age groups held a diploma or degree, more respondents aged 65-74 years (32.6\%) and 30-49 years (24.7\%) were professionals, compared to those aged 18-29 years (12\%) and 50-64 years (18.5\%). Again, more respondents aged $30-49$ years (22.1\%), followed by those aged $18-29$ years (17.6\%) and 50-64 years (14.8\%) held a postgraduate qualification (see Table 6).

\section{Ethical considerations}

Respondents participated of their own free will and had the opportunity to decline participation. No information was obtained that could personally identify respondents.

TABLE 3: Expenditures per person by age group for respondents at Table Mountain National Park.

\begin{tabular}{lccc}
\hline $\begin{array}{l}\text { Age groups } \\
\text { (years) }\end{array}$ & \multicolumn{3}{c}{ Total expenditure per person per day* } \\
\cline { 2 - 4 } & Total & Median & Quartile \\
\hline $18-29$ & $160^{\mathrm{a}}$ & 75 & 239 \\
$30-49$ & $120^{\mathrm{b}}$ & 35 & 170 \\
$50-64$ & $96^{\mathrm{a}, \mathrm{b}}$ & 78 & 154 \\
$65-74$ & $95^{\mathrm{a}, \mathrm{b}}$ & 35 & 175 \\
\hline $\mathrm{a}, \mathrm{b}$ & Different superscripts indicate significant differences amongst groups.
\end{tabular}

$\mathrm{a}, \mathrm{b}$, Different superscripts indicate significant differences amongst groups.

*, Kruskal-Wallis $p$-value $=0.04$

TABLE 4: Analysis of variance of reasons for the visit to Table Mountain Nationa Park by age group.

\begin{tabular}{ll}
\hline $\begin{array}{l}\text { Age groups } \\
\text { (years) }\end{array}$ & $\begin{array}{l}\text { Social interactions (means and standard } \\
\text { deviations)* }\end{array}$ \\
\hline $18-29$ & $3.36^{\mathrm{a}}$ \\
$30-49$ & $3.43^{\mathrm{a}}$ \\
$50-64$ & $3.10^{\mathrm{a}, \mathrm{b}}$ \\
$65-74$ & $2.60^{\mathrm{b}}$ \\
\hline
\end{tabular}

a,b, Different superscripts indicate significant differences amongst groups.

*, Kruskal-Wallis $p$-value $=0.00$

TABLE 5: Region of residence of respondents in Table Mountain National Park by age group.

\begin{tabular}{lcccc}
\hline $\begin{array}{l}\text { Age groups } \\
\text { (years) }\end{array}$ & \multicolumn{4}{c}{ Region of residence } \\
\cline { 2 - 5 } & $\begin{array}{c}\text { South } \\
\text { Africa (\%) }\end{array}$ & $\begin{array}{c}\text { North } \\
\text { America (\%) }\end{array}$ & $\begin{array}{c}\text { Europe } \\
(\mathbf{\%})\end{array}$ & $\begin{array}{c}\text { Other } \\
(\%)\end{array}$ \\
\hline $18-29$ & 32.5 & 6.1 & 45.6 & 15.8 \\
$30-49$ & 31.8 & 7.6 & 45.3 & 15.3 \\
\hline $50-64$ & 15.4 & 26.9 & 46.2 & 11.5 \\
$65-74$ & 16.3 & 30.2 & 44.2 & 9.3 \\
\hline
\end{tabular}

$\left[\chi^{2}(9=353)=30.1, p<0.01\right]$

TABLE 6: Education of respondents in Table Mountain National Park by age group.

\begin{tabular}{lccccc}
\hline $\begin{array}{l}\text { Age groups } \\
\text { (years) }\end{array}$ & $\begin{array}{c}\text { Matric } \\
\mathbf{( \% )}\end{array}$ & $\begin{array}{c}\text { Degree or } \\
\text { Diploma (\%) }\end{array}$ & $\begin{array}{c}\text { Postgraduate } \\
\text { qualification (\%) }\end{array}$ & $\begin{array}{c}\text { Professional } \\
\mathbf{( \% )}\end{array}$ & $\begin{array}{c}\text { Other } \\
(\%)\end{array}$ \\
\hline $18-29$ & 18.4 & 32.8 & 17.6 & 12.0 & 19.2 \\
\hline $30-49$ & 10.0 & 39.5 & 22.1 & 24.7 & 3.7 \\
\hline $50-64$ & 11.1 & 55.6 & 14.8 & 18.5 & 0.0 \\
$65-74$ & 18.6 & 37.2 & 9.3 & 32.6 & 2.3 \\
\hline
\end{tabular}

$\left[\chi^{2}(12=385)=47.12, p<0.01\right]$ 


\section{Trustworthiness}

The authors did everything in their power to ensure that the sample and the survey was conducted in a systematic and scientific manner. Results of the profile confirm previous research conducted in national parks.

\section{Discussion}

Unlike previous research, this study specifically targeted visitors to a national park on the basis of their travel expenditure patterns by age range, along with other sociodemographics and their reasons for the visit. The latter assisted with profiling the age groups and to match the 'product's' specificities with the public's specific demands.

From a theoretical standpoint, the findings differ from those detected by previous research. Then, too, some contradictions representing rich material to foster new research directions have been highlighted as follows.

Firstly, as expected by the researchers, a considerable number of younger respondents (18-29 years) (32.2\%) were detected in the area and this differs from the general notion and results by other researchers that mostly older people visit national parks. The low percentages of respondents older than 50 years (50-64 years, $7.2 \%$ and $65-74$ years, $12.1 \%$ ) were therefore unexpected, compared to previous findings (Beh \& Bruyere 2007; Galloway 2002; Kibicho 2006; Marques et al. 2010; Kruger et al. 2010; Saayman, Kruger \& Fouche 2009; The International Ecotourism Society 2006).

Secondly, the finding related to spending behaviour highlights the presence of a new and potentially lucrative market when compared to those detected by previous research (Kruger et al. 2010; Mehmetoglu 2007); that is, a younger segment of respondents aged 18-29 years. This group was characterised by the highest expenditure per person and a higher expenditure per person when compared to those aged 30-49 years. Then, younger respondents seem to represent a rather lucrative market, which would be a crucial variable for the maintenance and the sustainable growth of the area and is in line with the worldwide trends of youth tourism. The youth tourist sector, which accounts for $20 \%$ of the international tourism market, is growing faster than most other travel segments, with a global volume growth of $3 \%-5 \%$ a year and is valued at approximately $\$ 165$ billion per year. Estimates show that youth and student travel market will reach 300 million arrivals by 2020 and represent $\$ 320$ billion in market values (World Youth Student and Educational Travel Confederation 2011).

Furthermore, the reasons for visiting a national park showed some differences in terms of age groups. Specifically, significant differences were found for the motivational dimension 'social interactions': respondents aged 18-29 years and those aged 30-49 years revealed themselves to be more likely to be motivated by a possibility to spend time with family or friends, compared to the oldest group aged 65-74 years. Unlike past research (e.g. Moscardo \& Green 1999) that found differences concerning the activities participated in by respondents' age, no statistically significant differences were found here in regard to the motivational dimension 'activities and adventure sports performance' by age group. In addition, unlike past research (Kim, Lee \& Klenosky 2003), age groups reported similarities for most of the motivational factors detected.

Finally, it is worth noting that amongst those respondents who were not aware of being in a national park, the majority were younger than 50 years old (i.e. in the 18-29 years and 30-49 years age groups).

In brief, visitors participating in the research and aged 18-29 years were the second largest group and the heaviest spending segment per person. They were more motivated to visit for the day, when compared to respondents aged 65-74 years, because of the possibility of spending time with family (or someone special) and friends, they were less aware of being in a national park when compared to respondents aged 65-74 years, they mainly held a postgraduate qualification and largely came from Europe or South Africa. Those aged 30-49 were the largest group but the lowest spending segment per person; the rest of their profile is similar to that of the youngest group. No statistically significant results were detected for the older groups concerning their expenditure patterns.

\section{Practical implications}

Based on the findings of this research, some practical implications for the sustainable development and financing of the TMNP have been outlined. The promotion of a mere increase in the number of visitors to capture economic benefits is to be avoided because it may have a cost to the natural environment (see Eagles et al. 2002). Therefore, a demarketing strategy is considered necessary, but directed at the segment that showed the strongest propensity to spend (aged 18-29 years) and whose growth will help sustain the park. However, because the younger market at national parks is generally less present and known compared to the older segments, marketing to the younger groups should be conducted by first investigating the impacts of their activities. This relates also to Park visitor management capacity. By contrast, no marketing strategy should be considered for the next oldest age respondents (aged 30-49 years) who were found to be lower-spenders and whose numbers are already significant and stable in this particular National Park, as well as in worldwide national parks (e.g. Saayman, Kruger \& Fouche 2009).

\section{Recommendations}

The following are some ideas for a specific marketing strategy. Increasing the frequency of visits and attracting the younger market aged 18-29 years could be achieved by offering, for instance, a youth loyalty card, especially to those visitors residing in South Africa, of whom there are considerable numbers amongst the younger respondents. Hosting youth days might be another successful strategy to attract this market. In addition, a marketing strategy could include social-related content, as these respondents were 
found to be more likely to be motivated by the possibility of spending time with family and friends. For example, picnic and braai areas, such as the Buffels Bay and Bordjiesdrif, or the Tokai Picnic and Braai Area and its wide space for large groups, can be promoted. As an urban park offering several activities and adventure sports, a marketing strategy could be used also to target additional younger segments such as the 'harder eco-tourists' identified by Weaver and Lawton (2002) or the 'self-centred visitors' and the 'occasional visitors' identified by Marques et al. (2010), who reported a high propensity to take part in these types of activities.

Finally, as mostly younger participants seemed to be unaware they were in a national park, the management should provide more information about this. Educational programmes could represent another marketing tool for promoting repeated visits to the Park and, in general, to other national parks. In fact, several research findings have highlighted how practical experiences in outdoor settings, such as hands-on conservation activities and on-site educational programmes at an early age, shape and promote positive interests and associated behaviours towards the environment, thus ensuring nature conservation and preservation (McDuff \& Jacobson 2000; Palmer 1993; Sward 1996; Voordouw 1987).

\section{Limitations}

A limitation of the current research is the difficulty in generalising these results to a wider population of the Park. To test the general applicability of these findings to other samples, this study should be replicated. Secondly, previous research highlighted the importance of trip-related characteristics (e.g. type of accommodation, length of stay) for the spending segments characterisation. However, these variables could not be included in the present research because the TMNP, compared to other South African national parks, has a high percentage of day visitors and low percentage of repeat day visitors and overnight visitors (Saayman, Kruger \& Fouche 2009). This may be due, in part, to the fact that the majority of the visitors across all ages were foreigners from overseas visiting the TMNP as one of the stops on their tour. Therefore, the TMNP management should do more, in terms of marketing plans, to target the domestic visitor market, for example, by providing discounts and/or loyalty cards to South Africans. Thirdly, unlike most past research that found motivational differences by age, here the characterisation of the age groups may be considered as limited because just one factor of five motivational factors significantly differentiated the age groups. Future research is required to shed more light on this point. Fourthly, although past research highlighted the importance of the activities participated in, in terms of increasing expenditure patterns (Mehmetoglu 2007), this study was unable to find any differences in terms of the activities as reasons for the visit by the age (spending) segments. Further research should again be conducted to shed more light on this point. Finally, this study was unable to find any differences amongst the age groups in terms of expenditures per person for each of the categories considered (e.g. restaurants, food, etc.). However, it would be interesting to know what younger groups spent the extra money on. Future research should be conducted to shed more light on this point.

\section{Conclusion}

This research adds to existing literature by shedding more light on the expenditure patterns (behaviour) of a sample of visitors to the TMNP, grouped by age range, and contributes to the topic of visitor behaviours to nature-based attractions. The respondents' profile was found to differ significantly from the profiles of visitors to other parks, as the TMNP respondents are younger and most of them are foreigners. As parks are generally visited by older people, this study highlights the importance of a younger market. Future research in national parks should pay particular attention to this market, which was found as an emerging but very relevant economic market and is anticipated as playing a key role in supporting sustainable lifestyles in the future (Coetzee \& Saayman 2009; Council for Game and Wildlife Conservation 2003).

\section{Acknowledgements}

The authors want to acknowledge the following people and institutions. Firstly, SANParks for funding and allowing the research, especially, Mr Glenn Phillips and Bheki Zwane. Secondly, the National Research Foundation for funding this research. Thirdly, all the respondents for completing the questionnaires and, lastly, the reviewers for their valuable comments.

\section{Competing interests}

The authors declare that they have no financial or personal relationships that may have inappropriately influenced them in writing this article.

\section{Authors' contributions}

M.S. (North-West University) was the project leader in developing the questionnaire and conducting the survey. F.C. (North-West University) was the main author and also responsible for the statistical analysis. Both authors reviewed and finalised the article.

\section{References}

Beh, A.W. \& Bruyere, B.L., 2007, 'Segmentation by visitor motivation in threen Kenyan national reserves', Tourism Management 28, 1464-1471. http://dx.doi. org/10.1016/j.tourman.2007.01.010

Buckley, R., 1994, 'A framework for ecotourism', Annals of Tourism Research 21, $661-$ 669. http://dx.doi.org/10.1016/0160-7383(94)90126-0

Buckley, R., 2002a, A global triple-bottom-line evaluation for ecotourism, World Ecotourism Summit, Quebec.

Buckley, R., 2002b, 'Managing tourism in parks: Research priorities of industry associations and protected area agencies in Australia', Journal of Ecotourism 1, 162-172. http://dx.doi.org/10.1080/14724040208668122

Bushell, R. \& McCool, S.F., 2007, 'Tourism as a tool for conservation and support of protected areas', in R. Bushell \& P.F.J. Eagles (eds.), Tourism and protected areas: Benefits beyond boundaries, pp. 12-26, CABI International, Wallingford.

Bushell, R., Staiff, R. \& Eagles, P., 2007, 'Tourism and protected areas: Benefits beyond boundaries', in R. Bushell \& P.F.J. Eagles (eds.), Tourism and protected areas: Benefits beyond boundaries, pp. 1-11, CABI International, Wallingford.

Butler, R.W. \& Boyd, S.W., 2000, Tourism and national parks: Issues and implications, John Wiley and Sons, New York.

Cha, S., McCleary, K.W. \& Uysal, M., 1995, 'Travel motivations of Japanese overseas travellers: A factor-cluster segmentation approach', Journal of Travel Research 34, 33-39. http://dx.doi.org/10.1177/004728759503400104

Chhabra, D., 2007, 'Estimating benefits and costs of casino gambling in lowa, United States', Journal of Travel Research 46, 173-182. 
Child, B. \& Dalal-Clayton, B., 2004, 'Transforming approached to CBNRM: Learning from the Luangwa Experience, Zambia', in T.O. McShane \& M.P. Wells (eds.) Getting biodiversity projects to work: Towards more effective conservation and Getting biodiversity projects to work: Towards more effective cons
development, pp. 256-289, Columbia University Press, New York.

Coetzee, W. \& Saayman, M., 2009, 'Sustainability and ecotourism', in M. Saayman (ed.), Ecotourism - Getting back to basics, pp. 124-146, Leisure Publications, Potchefstroom. PMid:19290941

Council for Game and Wildlife Conservation, 2003, 'Young people: The biggest lobby group for sustainable use', African Indaba 1, 4-6.

Crompton, J.L., 1979, 'Motivations for pleasure vacation', Annals of Tourism Research 6, 408-424. http://dx.doi.org/10.1016/0160-7383(79)90004-5

Crompton, J.L. \& McKay, S.L., 1997, 'Motives of visitors attending festival events', Annals of Tourism Research 24, 425-439. http://dx.doi.org/10.1016/S0160 7383(97)80010-2

Down, D., 2000, Family spending: A report on the 1999-2000 Family Expenditure Survey, The National Statistics Office, London. PMCid:PMC3695199

Downward, P. \& Lumsdon, L., 2004, 'Tourism transport and visitor spending', Journal of Travel Research 42, 415-420. http://dx.doi.org/10.1177/0047287504263038

Eagles, P.F.J., McCool, S.P. \& Haynes, C.D., 2002, Sustainable tourism in protected areas. Guidelines for planning and management, IUCN publications services unit, Cambridge.

Frochot, I. \& Morrison, A.M., 2000, 'Benefit segmentation: A review of its applications to travel and tourism research', Journal of Travel \& Tourism Marketing 9, 21-45. http://dx.doi.org/10.1300/J073v09n04_02

Galloway, G., 2002, 'Psychographic segmentation of park visitor markets: Evidence for the utility of sensation seeking', Tourism Management 23, 581-596. http://dx.doi org/10.1016/S0261-5177(02)00025-0

Geldenhuys, S. \& Saayman, M., 2009, 'Ecotourism venues', in M. Saayman (ed.), Ecotourism - Getting back to basics, pp. 26-42, Leisure Publications, Potchefstroom.

Gibson, H., Attle, S.P. \& Yiannakis, A., 1998, 'Segmenting the active sport tourist market: A life span perspective', Journal of Vacation Marketing 4, 52-64. http:// dx.doi.org/10.1177/135676679800400105

Iso-Ahola, S.E., 1999, 'Motivational foundations of leisure', in E.L. Jackson \& T.L. Burton (eds.), Understanding leisure recreation, mapping the past, charting the future, pp. 35-51, Venture Publishing, State College.

Israel, G.D., 2009, Determining sample size, Florida State University, Cooperative Extension Service, Gainesville.

International Union for Conservation of Nature, 2004a, 2003 Durban World Park Congress, Protected areas programme, Gland.

International Union for Conservation of Nature, 2004b, Can protected areas contribute to poverty reduction?, IUCN, Gland.

Jang, S., Ismail, J.A. \& Ham, S., 2002, 'Heavy spenders, medium spenders, and light spenders of Japanese outbound pleasure travelers', Journal of Hospitality \& spenders of Japanese outbound pleasure travelers', Journal of Hosp
Leisure Marketing 9, 83-106. http://dx.doi.org/10.1300/J150v09n03_07

Jang, S.C., Bai, B., Hong, G.S. \& O'Leary, J.T., 2004, 'Understanding travel expenditure patterns: A study of Japanese pleasure travelers to the United States by income level', Tourism Management 25, 331-341. http://dx.doi.org/10.1016/S02615177(03)00141-9

Johns, N. \& Gymothy, S., 2002, 'Market segmentation and the prediction of tourist behavior: The case of Bornholm, Denmark', Journal of Travel Research 40, 316327. http://dx.doi.org/10.1177/0047287502040003009

Jönsson, C. \& Devonish, D., 2008, 'Does nationality, gender and age affect travel motivation? A case of visitors to the Caribbean island of Barbados', Journal of Travel and Tourism Marketing 25, 398-408. http://dx.doi. org/10.1080/10548400802508499

Kibicho, W., 2006, 'Tourists to Amboseli National Park: A factor-cluster segmentation analysis', Journal of Vacation Marketing 12, 218-231. http://dx.doi org/10.1177/1356766706064618

Kim, K., Jogaratnam, G. \& Noh, J., 2006, 'Travel decisions of students at a US university: Segmenting the international market', Journal of Vacation Marketing 12, 345357. http://dx.doi.org/10.1177/1356766706067606

Kim, S.S., Lee, C. \& Klenosky, D.B., 2003, 'The influence of push and pull factors at Korean national parks', Tourism Management 24(2), 169-180.

Kotler, P., 1992, 'Total marketing', Business Week Advance, Executive Brief 2.

Kruger, M. \& Saayman, M., in review, 'Segmenting visitors to the Addo Elephant National Park based on education level', Journal of Tourism Research and Hospitality, submitted 2013.

Kruger, M., Saayman, M. \& Saayman, A., 2010, 'Expenditure-based segmentation of visitors to Tsitsikamma National Park', Acta Commercii 10(1), 137-149.

Mabunda, D.M. \& Wilson, D., 2009, 'Commercialization of national parks: South Africa's Kruger National Park as an example', in J. Saarinen, F. Becker, H. Manwa $\&$ D. Wilson (eds.), Sustainable tourism in southern Africa, pp. 116-133, Channel View Publications, Bristol.

Marques, C., Reis, E. \& Menezes, J., 2010, 'Profiling the segments of visitors in Portuguese protected areas', Journal of Sustainable Tourism 18, 971-996. http:// dx.doi.org/10.1080/09669582.2010.497222

McDuff, M. \& Jacobson, S., 2000, 'Impacts and future directions of youth conservation organizations: Wildlife clubs in Africa', Wildlife Society Bulletin 28, 414-425.

Mehmetoglu, M., 2007, 'Typologising nature-based tourists by activity - Theoretical and practical implications', Tourism Management 28, 651-660. http://dx.doi. org/10.1016/j.tourman.2006.02.006
Mok, C. \& Iverson, T.J., 2000, 'Expenditure-base segmentation: Taiwanese tourists to Guam', Tourism Management 21, 299-305. http://dx.doi.org/10.1016/S02615177(99)00060-6

Moscardo, G. \& Green, D., 1999, 'Age and activity participation on the Great Barrier Reef', Tourism Recreation Research 24, 57-68.

Moutinho, L., 1987, 'Consumer behaviour in tourism', European Journal of Marketing 21, 5-44. http://dx.doi.org/10.1108/EUM0000000004718

Myburgh, E. \& Saayman, M., 1999, Ecotourism in action: Practical guidelines and principles, 1st edn., Leisure Consultants and Publications, Potchefstroom.

Oberholzer, S., Saayman, M., Saayman, A. \& Slabbert, E., 2010, 'The socio-economic impact of Africa's oldest marine park', Koedoe 52(1), 1-9.

Oh, Y.J., Cheng, C.K., Lehto, X.Y. \& O'Leary, J.T., 2004, 'Predictors of tourists' shopping behaviour: Examination of socio-demographic characteristics and
trip typologies', Journal of Vacation Marketing 10, 308-319. http://dx.doi. trip typologies', Journal of Vacation
org/10.1177/135676670401000403

Palmer, J., 1993, 'Development of concern for the environment and formative experiences of educators', Journal of Environmental Education 24, 26-30. http:// dx.doi.org/10.1080/00958964.1993.9943500

Patterson, I. \& Pegg, S., 2009, 'Marketing the leisure experience to baby boomers and older tourists', Journal of Hospitality Marketing \& Management 18, 254-272. http://dx.doi.org/10.1080/19368620802594136

Richards, G. \& Wilson, J.Y., 2003, New horizons in independent youth and student travel, A report for the International Student Travel Confederation and the Association of Tourism and Leisure Education, ISTC, Amsterdam.

Saayman, M., 2009, 'Community tourism', in M. Saayman (ed.), Ecotourism - Getting back to basics, pp. 67-96, Leisure Publications, Potchefstroom.

Saayman, M. \& Slabbert, E., 2004, 'A profile of tourists visiting the Kruger National Park', Koedoe 47, 1-8. http://dx.doi.org/10.4102/koedoe.v47i1.74

Saayman, M., Saayman, A. \& Du Plessis, C., 2005, 'Analysis of spending patterns of visitors of three World Cup Cricket matches in Potchefstroom, South Africa', Journal of Sport Tourism 10, 211-221. http://dx.doi.org/10.1080/14775080600611491

Saayman, M., Kruger, M. \& Fouche, M., 2009, Executive summary of research profiles of selected national parks in South Africa, Institute for Tourism and Leisure Studies, Potchefstroom.

Saayman, M., Saayman, A. \& Ferreira, M., 2009, 'The socio-economic impact of the Karoo National Park', Koedoe 51(1), 158-168.

Saayman, M., Van der Merwe, P. \& Pienaar, J., 2009, 'Expenditure-based segmentation of tourists to the Kruger National Park', Acta Academica 41, 107-127.

Seaton, A.V., 1996, 'The analysis of tourism demand: Market segmentation', in A.V. Seaton \& M.M. Bennett (eds.), Marketing tourism products, pp. 28-54, International Thomson Business Press, London.

Sherman, E. \& Schiffman, L.G., 1991, 'Quality-of-life (QOL) assessment of older consumers: A retrospective review', Journal of Business and Psychology 6, 107consumers: A retrospective review', Journal

South African National Parks, 2010, Annual report 2009-2010, viewed 20 January 2011, from http://www.sanparks.org/about/annual/default.php

South African National Parks, 2012, Annual report 2011-2012, viewed 20 November 2012, http://www.sanparks.org/about/annual/default.php

Spotts, D.M. \& Mahoney, E.M., 1991, 'Segmenting visitors to a destination region based on the volume of their expenditure', Journal of Travel Research 29, 24-31. $\mathrm{http}: / / \mathrm{dx}$.doi.org/10.1177/004728759102900405

SPSS version 18.0 for Windows, 2009, computer software, SPSS Inc., Chicago.

Sward, L., 1996, 'Experiential variables affecting the environmental sensitivity of El Salvadoran environmental professionals', Paper presented at the annual conference of the North American Association of Environmental Education, conference of the North American Associngame, California, 01-02 November.
Burlingatis

The International Ecotourism Society, 2006, Global ecotourism fact sheet, viewed 21 January 2011, from http://mekongtourism.org/website/wp-content/uploads/ downloads/2011/02/Fact-Sheet-Global-Ecotourism-IETS.pdf

Thrane, C. \& Farstad, E., 2011, 'Domestic tourism expenditures: The non-linear effects of length of stay and travel party size', Tourism Management 32, 46-52.

Voordouw, J.J., 1987, Youth in environmental action: An international survey, joint publication by International Youth Foundation, International Union for the Conservation of Nature and United Nations Environment Programme, Gland.

Waite, C., n.d., Travel features: South Africa - Cape Town, viewed 21 February 2014, from http://www.boardseekermag.com/travel_features/southAfrica/south africa.htm

Weaver, D.B. \& Lawton, L.J., 2002, 'Overnight ecotourist market segmentation in the Gold Coast Hinterland of Australia', Journal of Travel Research 40, 270-280.

World Commission on Protected Areas, 1998, Economic values of protected areas: Guidelines for protected area managers, joint publication by Task Force on Economic Benefits of Protected Areas of the World Commission on Protected Areas and Econ
Nature, Gland.

World Tourism Organization, 2002, Sustainable development of ecotourism: A compilation of good practices, WTO, Madrid.

World Wildlife Fund International, 2001, Guidelines for community-based development, WWFI, Ledbury.

World Youth Student and Educational Travel Confederation, 2011, The power of youth travel, viewed 21 February 2014, from http://wysetc.org/publications/power-ofyouth-travel/ 